\title{
WHAM evidence summary: Use of yoghurt for managing malodorous wounds
}

Keywords Wound odour, malodorous wound, yoghurt

For referencing Watts R and Solomons T. WHAM evidence summary: Use of yoghurt for managing malodorous wounds. WCET ${ }^{\oplus}$ Journal 2021;41(4):22-24

DOI https://doi.org/10.33235/wcet.41.4.22-24

\section{CLINICAL QUESTION}

What is the best available evidence in the effectiveness of treating yoghurt for managing malodorous wounds?

\section{SUMMARY}

Malodour can occur in chronic wounds (e.g., tumours, pressure injuries and venous ulcers). The combination of anaerobic bacterial colonisation, biofilm and necrotic tissue produces the odour. Unless the odour and exudate from malodorous wound(s) are significantly reduced they might have both physical and psychological impacts on the individual with a wound, including embarrassment, depression and social isolation'. Despite a detailed literature search, no evidence has been found that supports the use of yoghurt for reducing malodour in chronic wounds. Research on the effectiveness of probiotics may provide evidence in this field in the future. ${ }^{2}$

\section{Clinical practice recommendations}

All recommendations should be applied with consideration to the wound, the person, the health professional and the clinical context.

There is insufficient evidence on the effectiveness of yoghurt products to make a graded recommendation on their use in reducing odour in chronic wounds.

\section{Sources of evidence: search and appraisal}

This summary was developed using methods published by the Joanna Briggs Institute (JBI) ${ }^{3-7}$. The summary is based on a

\section{Robin Watts*}

AM, PhD, MHSc, BA, Dip NEd, FRCNA

Emeritus Professor, Curtin University, School of Nursing, Midwifery and Paramedicine, Wound Healing and Management (WHAM) unit

\section{Terena Solomon}

BA, Grad Dip Lib Sc ALIA

Curtin University

* Corresponding author systematic literature search in English combining search terms that describe malodorous wounds and yoghurt (yoghurt OR live bacillus acidophilus) AND (wound odour OR malignant fungating wound* OR malodorous wound*). Searches were conducted in Embase, Medline, the Cochrane Library, CINAHL, Scopus, Epistimonikos and Google Scholar for dates up to August 2021. Studies were assigned a level of evidence (see Table One) based on JBI's hierarchy ${ }^{3-7}$. Recommendations are made based on the body of evidence and are graded according to the system reported by $\mathrm{JB} \mathrm{P}^{3-7}$.

\section{BACKGROUND}

Over time, numerous solutions have been employed in treating the problem of wound odour, some with success ${ }^{8}$. However, research into comparative effectiveness of different strategies to manage wound odour is lacking. One author refers to 'trial and error' being the process of assessing the most effective or ineffective treatments. ${ }^{9}$ It is only recently that controlled trials have been implemented to provide some certainty of effectiveness ${ }^{10}$. The results of these studies have now been combined in several systematic reviews ${ }^{11-13}$.

With commercial development of various treatments, wound malodour can be managed promptly. However, in low resource contexts, wound odour management strategies such as specialised dressings and pharmaceutical products can be beyond the financial reach of the health service or the individual.

Consequently, cheaper alternative methods of treatment have been sought. While some have evidence supporting their use, others have proved unsuccessful in attaining significant clinical benefit, and some are yet to be formally studied. Yoghurt falls into the latter category.

\section{EVIDENCE}

Although several journal articles in the 1980s and 1990s mentioned plain live yoghurt in treating wound malodour and exudate, their reports do not provide a research plan nor any 


\begin{tabular}{|l|l|l|l|l|l|}
$\begin{array}{l}\text { Level } 1 \text { evidence: } \\
\text { Experimental designs }\end{array}$ & $\begin{array}{l}\text { Level } 2 \text { evidence: } \\
\text { Quasi-experimental } \\
\text { designs }\end{array}$ & $\begin{array}{l}\text { Level } 3 \text { evidence: } \\
\text { Observational - analytic } \\
\text { designs }\end{array}$ & $\begin{array}{l}\text { Level 4 evidence: } \\
\text { Observational - } \\
\text { descriptive studies }\end{array}$ & $\begin{array}{l}\text { Level } 5 \text { evidence: } \\
\text { Expert opinion / bench } \\
\text { research }\end{array}$ \\
\hline Nil & Nil & Nil & Nil \\
\hline
\end{tabular}

data. Among those who considered the use of yoghurt in this period were Benbow, Welch, Schulte, and Haughton and Young with their personal speculations as to how the yoghurt might work ${ }^{14-17}$ to reduce wound odour.

Haughton and Young declared that yoghurt should not be used due to the possibility of infection from Lactobacillus, leading to this treatment being ceased in many clinical settings despite there being no evidence supporting the claim ${ }^{15}$. The laboratory development of a unique probiotics-based milk peptide plus hydrogel may challenge this idea. Recent work promoting wound healing via the use of probiotic bacteria or their extracts involves lysates of Lactobacillus, and to date has shown initial promising results ${ }^{2}$.

\section{CONSIDERATIONS FOR USE}

Consider using alternative low cost treatments to manage malodorous wounds, including green tea ${ }^{18}$, medical-grade honey ${ }^{19}$, sugar paste ${ }^{15}$, or rice bran sheets ${ }^{20}$.

\section{CONFLICTS OF INTEREST}

The author declares no conflicts of interest in accordance with International Committee of Medical Journal Editors (ICMJE) standards.

\section{ABOUT WHAM EVIDENCE SUMMARIES}

WHAM evidence summaries are consistent with methodology published in:

Munn Z, Lockwood C, Moola S. The development and use of evidence summaries for point of care information systems: $A$ streamlined rapid review approach, Worldviews Evid Based Nurs. 2015;12(3):131-8.

Methods are outlined in detail in resources published by the Joanna Briggs Institute as cited in this evidence summary. WHAM evidence summaries undergo peer-review by an international multidisciplinary Expert Reference Group. WHAM evidence summaries provide a summary of the best available evidence on specific topics and make suggestions that can be used to inform clinical practice. Evidence contained within this summary should be evaluated by appropriately trained professionals with expertise in wound prevention and management, and the evidence should be considered in the context of the individual, the professional, the clinical setting and other relevant clinical information.

Copyright $\odot 2021$ Wound Healing and Management Unit, Curtin Health Innovations Research Institute, Curtin University

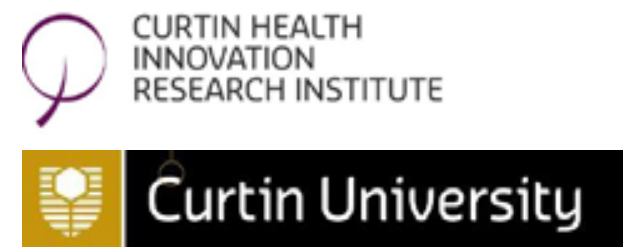

\section{REFERENCES}

1. Patel B, Cox-Hayley D. Managing wound odor. J Palliat Med, 2010;13(10):1286-7.

2. Mohammedsaeed W, Cruickshank S, McBain AJ, O'Neill CA. Lactobacillus rhamnosus GG lysate increases re-epithelialization of keratinocyte scratch assays by promoting migration. Scientific reports, 2015;5:16147.

3. Munn Z, Lockwood C, S. M. The development and use of evidence summaries for point of care information systems: A streamlined rapid review approach. Worldviews Evid Based Nurs, 2015;12(3):1318.

4. Aromataris E, Munn Z, editors. JBI 2021. Manual for Evidence Synthesis. https://synthesismanual.jbi.global: Joanna Briggs Institute.

5. Joanna Briggs Institute Levels of Evidence and Grades of Recommendation Working Party. New JBI Grades of Recommendation. 2013. https://jbi.global/sites/default/ files/2019-05/JBI-grades-of-recommendation_2014.pdf: Joanna Briggs Institute.

6. Joanna Briggs Institute Levels of Evidence and Grades of Recommendation Working Party. Supporting Document for the Joanna Briggs Institute Levels of Evidence and Grades of Recommendation. 2014. https://jbi.global/sites/ default/files/2019-05/JBI\%20Levels\%20of\%20Evidence\%20 Supporting\%20Documents-v2.pdf: Joanna Briggs Institute.

7. Joanna Briggs Institute Levels of Evidence and Grades of Recommendation Working Party. JBI Levels of Evidence. 2013. https://jbi.global/sites/default/files/2019-05/JBI-Levels-ofevidence_2014_0.pdf: Joanna Briggs Institute.

8. Akhmetova A, Saliev T, Allan IU, Illsley MJ, Nurgozhin T, Mikhalovsky S. A comprehensive review of topical odor-controlling treatment options for chronic wounds. J Wound Ostomy Cont Nurs, 2016;43(6):598-609.

9. Gethin G, Grocott P, Probst S, Clarke E. Current practice in the management of wound odour: An international survey. Int J Nurs Stud, 2014;51(6):865-74.

10. Villela-Castro DL, Santos VL, Woo K. Polyhexanide versus metronidazole for odor management in malignant (fungating) wounds: a double-blinded, randomized, clinical trial. J Wound Ostomy Cont Nurs, 2018;45(5).

11. da Costa Santos CM, de Mattos Pimenta CA, Nobre MRC. A systematic review of topical treatments to control the odor of malignant fungating wounds. Journal of Pain and Symptom Management, 2010;39(6):1065-76. 
12. Winardi A, Irwan AM. Topical treatment for controlling malignant wound odour. EWMA Journal, 2019;20(2):7-15.

13. Caldeira Brant JM, Teodora da Silva LH. Efetividade do metronidazol tópico e/ou sistêmico no controle do mau odor de tumores malignos fétidos: revisão sistemática. Revista da Faculdade de Odontologia de Porto Alegre, 2021;62(1):121-8.

14. Benbow M. Malodorous wounds: how to improve quality of life. Community Nurse, 1999;5(1):43-6.

15. Haughton W, Young T. Common problems in wound care: malodorous wounds. Br J Nurs, 1995;4(16):959-63.

16. Schulte MJ. Yogurt helps to control wound odor. Onc Nurs Forum, 1993;20(8):1262.

17. Welch LB. Buttermilk \& yogurt: odor control of open lesions. Crit Care Update, 1982;9(11):39-44.

18. Lian SB, Xu Y, Goh SL, Aw FC. Comparing the effectiveness of green tea versus topical metronidazole powder in malodorous control of fungating malignant wounds in a controlled randomised study. Proceedings of Singapore Healthcare, 2014;23(1):3-12.

19. Samala RV, Davis MP. Comprehensive wound malodor management: Win the RACE. Cleve Clin J Med, 2015;82(8):535-43.

20. Hayashida K, Ogino R, Yamakawa S, Shirakami E. Antiodor effects of rice bran sheets in patients with malodorous wounds. J Palliat Med, 2020;23(6):750-1. 